\title{
ЄДИНИЙ МЕДИЧНИЙ ПРОСТІР УКРАЇНИ В ПАРАДИГМІ РОЗВИТКУ ВІТЧИЗНЯНОГО АДМІНІСТРАТИВНОГО ПРАВА
}

Сіделковський О. Л.

Стаття присвячена проблематиці формування єдиного медичного простору України у парадигмі розвитку вітчизняного адміністративного права. Констатовано, що медична реформа зумовлює необхідність розробки адекватних заходів правового регулювання, передовсім адміністративно-правового. Стверджується про доцільність початкового виокремлення принципів формування єдиного медичного простору України. Вони мають стати певного роду «дороговказом» для реформування системи охорони здоров'я.

Акцентується увага на тій обставині, що нині ми є свідками активного етапу здійснення медичної реформи в Україні. Є всі підстави говорити про те, що за певними ознаками це найбільш дієвий варіант їі проведення порівняно з іншими спробами реформування вітчизняної системи охорони здоров'я.

Ключові слова: єдиний медичний простір, медичне право, адміністративне право, права пацієнтів, медична реформа.

Статья посвящена проблематике формирования единого медицинского пространства Украины в парадигме развития отечественного административного права. Констатировано, что медицинская реформа обусловливает необходимость разработки адекватных мер правового регулирования, прежде всего административно-правового. Утверждается о целесообразности начального выделения принципов формирования единого медицинского пространства Украины. Они должны стать своего рода «путеводителем» для реформирования системы здравоохранения.

Акцентируется внимание на том обстоятельстве, что сейчас мы являемся свидетелями активного этапа осуществления медицинской реформы в Украине. Есть все основания говорить о том, что по определённым признакам это наиболее действенный вариант её проведения по сравнению с другими попытками реформирования отечественной системы здравоохранения.

Ключевые слова: единое медицинское пространство, медицинское право, административное право, права пациентов, медицинская реформа.

The article is devoted to the problem of formation of the single medical space of Ukraine in the paradigm of development of national administrative law. It is stated that medical reform necessitates the development of adequate legal regulation measures, first of all administrative and legal ones.

It is argued that it is advisable to initially identify the principles of forming a single medical space in Ukraine. They have to become a kind of "guide" to reforming the health care system.

Attention is drawn to the fact that we are currently witnessing an active phase in the implementation of medical reform in Ukraine. There is every reason to say that this is by far the most viable option compared to other attempts to reform the national healthcare system.

The author presents arguments that prove the importance of forming a single medical space in terms of legal reality. These

Сіделковський О. Л., 2019 include the following: the presence of a normatively defined division of the health care system into public, communal and private ones, which, subject to the introduction of a single medical space, causes a certain unification of the activities of the respective medical institutions; the combination of the need to create a single medical space with the implementation of medical reform in Ukraine during 2016-2019, which is primarily aimed at changing the system of financing the medical sector; Ukraine's European integration aspirations cannot be ignored in the construction of Ukraine's single medical space. If our country's public policy has been built for more than one year, taking into account the potential accession of Ukraine to the European Union, then we must take this fact into account in finding ways to improve the legal regulation of medical activity.

The article raises the question that the only medical space, considered in the theoretical and methodological dimension, necessitates the formulation of a question and proposals for its solution in the context of constitutionally defined free medical care.

It was stated that the paradigm of administrative law development, based on the principles of human-centrism, is able to ensure priority of patients' rights, freedoms and legitimate interests in the provision of medical care. Undoubtedly, in the sphere of medical activity, when forming a state of a single medical space, the approach should be just as follows: a person should be perceived as the main "addressee" of the public authority's duties, that is, an entity to which the state should "serve".

Key words: common medical space, medical law, administrative law, patients' rights, medical reform.

Миє свідками того, що нині стрімко розвиваються нові напрями суспільного життя, що, відповідно, зумовлює оновлення суспільних відносин, які при цьому виникають. Не $\epsilon$ винятком і медична діяльність, сфера охорони здоров' я загалом. Медична реформа зумовлює необхідність розробки адекватних заходів правового регулювання, передовсім адміністративно-правового. Вони, своєю чергою, мають перебувати у парадигмі розвитку вітчизняного адміністративного права. Це важливо для того, щоб вони: а) були життєздатними; б) характеризувались перспективністю, тобто можливістю зберігати свій регулюючий потенціал через тривалий період часу.

Необхідність наукової розвідки проблематики єдиного медичного простору України у парадигмі розвитку вітчизняного адміністративного права зумовлена таким:

1. Єдиний медичний простір - відносно нове явище для вітчизняної охорони здоров'я та практично нерозроблене (недосліджене) у рамках правової науки загалом та адміністративно-правової зокрема.

2. Поєднання необхідності формування єдиного медичного простору з проведенням у нашій державі протягом 2016-2018 рр. медичної реформи, яка передовсім спрямована на зміну системи фінансування медичної галузі.

3. Наявність нормативно визначеного поділу системи охорони здоров' я на державну, комунальну та при- 
ватну, що за умови впровадження єдиного медичного простору зумовлює певну уніфікацію діяльності відповідних медичних закладів.

4. Конституційно визначена у статті 49 Основного Закону держави безоплатність надання медичної допомоги у державних та комунальних закладах охорони здоров'я має бути врахована у формуванні єдиного медичного простору. При цьому важливо вибудувати таку модель фінансових розрахунків, щоб як для державних та комунальних, так і для приватних медичних закладів така система була не тільки соціально, але й економічно привабливою.

5. Доцільність початкового виокремлення принципів формування єдиного медичного простору України. Вони мають стати певного роду «дороговказом» для реформування системи охорони здоров'я.

6. Євроінтеграційні прагнення нашої держави не можуть не бути враховані у разі побудови єдиного медичного простору України. Якщо публічна політика нашої держави уже не один рік будується з урахуванням потенційного вступу України до Європейського Союзу, то ми маємо ураховувати цей факт у пошуку шляхів удосконалення правового регулювання медичної діяльності.

7. Загальноправова та загальносоціальна тенденція щодо уніфікації підходів до врегулювання (упорядкування) тих чи інших соціальних процесів. Такого роду тенденція має бути врахована у формуванні єдиного медичного простору України [1, с. 55].

Основи законодавства України про охорону здоров'я від 19 листопада 1992 року № 2801-XII містять визначення, відповідно до якого охорона здоров'я - це система заходів, що здійснюються органами державної влади та органами місцевого самоврядування, їх посадовими особами, закладами охорони здоров'я, фізичними особами-підприємцями, які зареєстровані в установленому законом порядку та одержали ліцензію на право провадження господарської діяльності з медичної практики, медичними та фармацевтичними працівниками, громадськими об'єднаннями і громадянами з метою збереження та відновлення фізіологічних і психологічних функцій, оптимальної працездатності та соціальної активності людини за максимальної біологічно можливої індивідуальної тривалості її життя. Стаття 33 цього нормативно-правового акта «Забезпечення надання медичної допомоги» свідчить, що медична допомога надається відповідно до медичних показань професійно підготовленими медичними працівниками, які перебувають у трудових відносинах із закладами охорони здоров'я, що забезпечують надання медичної допомоги згідно з одержаною відповідно до закону ліцензією, та фізичними особами- підприємцями, які зареєстровані та одержали відповідну ліцензію в установленому законом порядку і можуть перебувати з цими закладами у цивільно-правових відносинах. Медична допомога за видами поділяється на екстрену, первинну, вторинну (спеціалізовану), третинну (високоспеціалізовану), паліативну, медичну реабілітацію [2].

Формально кажучи, ми бачимо, що «медична конституція», як нерідко називають Основи законодавства України про охорону здоров'я, ставить знак рівності між найтиповішими представниками: державними, комунальними та приватними закладами охорони здоров'я. Все це, здавалося б, наштовхує на думку про реальне існування єдиного медичного простору, де на рівних правах існують усі вищеперераховані суб'єкти. Проте на практиці це не так. Приватні заклади мають обмежену можливість конкурувати за, скажімо, бюджетні кошти, що виділяються на лікування пацієнтів. Чи зможе медична реформа, що нині проводиться в Україні, змінити ситуацію?

Схоже на те, як стверджує С.Г. Стеценко, що нинішній етап медичної реформи в України носить більш системний характер, оскільки він проявляється низкою характерних особливостей, які відрізняють його від попередніх, зокрема:

по-перше, він підкріплений нормативно-правовими змінами чинного законодавства. Причому йдеться не про внесення змін та доповнень до наявних законів, а появою нових законів, положення яких спрямовані на врегулювання суспільних відносин у сфері медичної діяльності;

- по-друге, відбувається фактична спроба розділити обов'язки щодо фінансування медичної допомоги між державою, місцевим самоврядуванням та громадянами України. Без внесення змін до статті 49 Конституції України [3, с. 57-58].

Нині ми $€$ свідками активного етапу здійснення медичної реформи в Україні. $Є$ всі підстави говорити про те, що за певними ознаками це найбільш дієвий варіант ऑї проведення порівняно з іншими спробами реформування вітчизняної системи охорони здоров'я. Наскільки він $\epsilon$ ефективним та суспільно корисним, ми зможемо оцінити пізніше, проте вже зараз можемо констатувати таке:

1) ці зміни відчувають усі: пацієнти, лікарі, суспільство і держава загалом. Перші дві категорії поки що переважно на рівні підсвідомості, проте $\epsilon$ і суто реальні кроки, як-то старт з 1 квітня поточного року вибору лікаря первинної ланки надання медичної допомоги;

2) створено абсолютно новий державний орган Національну службу здоров'я України. За формальними ознаками це центральний орган виконавчої влади, за фактичними - основний «тримач коштів», які держава виділятиме на фінансування надання медичної допомоги;

3) швидкість проведення медичної реформи. Вона $\epsilon$ істотною. Поява нового закону, видання низки підзаконних нормативно-правових актів, впровадження нових організаційно-правових механізмів всередині сфери охорони здоров'я, все це відбувається протягом місяців [4, с. 128].

Нині варто навести аргументи, котрі свідчать про важливість формування єдиного медичного простору з точки зору правової дійсності. До них можуть бути віднесені такі:

1. Наявність нормативно визначеного поділу системи охорони здоров'я на державну, комунальну та приватну, що за умови впровадження єдиного медичного простору зумовлює певну уніфікацію діяльності відповідних медичних закладів.

2. Поєднання необхідності формування єдиного медичного простору з проведенням у нашій державі протягом 2016-2019 рр. медичної реформи, яка передовсім спрямована на зміну системи фінансування медичної галузі.

3. Євроінтеграційні прагнення нашої держави не можуть не бути враховані під час побудови єдиного медичного простору України. Якщо публічна політика 
нашої держави уже не один рік будується з урахуванням потенційного вступу України до Європейського Союзу, то ми маємо ураховувати цей факт у пошуку шляхів удосконалення правового регулювання медичної діяльності.

Єдиний медичний простір має формуватися на засадах людиноцентризму. Пацієнт має бути метою здійснення такого роду реформ. Ми поділяємо думку Р.С. Мельника, який зазначає, що сучасне адміністративне право виконує ті завдання, які були невідомі цій галузі права попереднього історичного періоду розвитку нашої правової системи. Концепція людиноцентризму, орієнтація на практику Європейського суду з прав людини, євроінтеграційні прагнення України, принцип верховенства права - це лише частина юридичних явищ та категорій, які визначають мету адміністративного права, впливають на внутрішню структуру та формують предмет його регулювання [5, с. 47].

Певного роду містком між проблематикою адміністративно-правового забезпечення медичної галузі та створенням єдиного медичного простору має бути напрацювання механізмів взаємодії лікувально-профілактичних закладів різної форми власності та підпорядкування: державних, приватних, комунальних, відомчих. Для їх функціонального поєднання необхідно напрацювати механізм, який дасть змогу, з одного боку, забезпечувати права пацієнтів на якісну та доступну медичну допомогу, проте з іншого - міститиме економічні стимули брати участь у функціонуванні єдиного медичного простору; не йтиме всупереч ідеології децентралізації, що активно пропагується у державі; відповідатиме правовим та іншим традиціям українського суспільства.

Звідси постає питання: якщо для людини здоров'я - це важлива соціальна цінність, яка підтверджується державою, то чи $\epsilon$ у людини право на здоров'я? Це питання не $\epsilon$ надто простим. Правова наука та наука адміністративного права не дає на це питання однозначної відповіді. Право на здоров'я, на думку О.В. Тихомирова, $є$ природним правом людини. Його не можна заборонити, позбавити цього права його носія або обмежити в цьому праві. Ним володіють і здорові, i хворі, в тому числі душевнохворі. В тому сенсі право на здоров'я асоційоване з правом на життя, слідуючи йому, і поняттям правоздатності. Обмеження або втрата дієздатності не позбавляє і не применшує права на здоров'я, як і самого цього блага [6, с. 33]. Варто зазначити, що не зі всіма із вказаних аргументів необхідно погодитись. Сумніви викликає таке:

чому право на здоров'я - це природне право? Хіба воно рівнозначне праву на життя? Хіба воно в одному із ним порядку, на одному рівні?

хіба не можна (нехай навіть у теоретико-методологічному вимірі) обмежити в цьому праві? Приміром, засуджений, який страждає певним захворюванням, об'єктивно потребує надання медичної допомоги, проте у доступі до неї адміністрація установи виконання покараньйомувідмовляє. Ценеобмеженняправаназдоров'я?

Єдиний медичний простір, що розглядається у теоретико-методологічному вимірі, зумовлює необхідність постановки питання та пропозицій щодо його вирішення у контексті конституційно визначеної безоплатності медичної допомоги. Як стверджують С.Г. Стеценко та В.О. Галай, конституційно визначені права людини і громадянина у сфері охорони здоров'я включають у себе:

1. Права, які безпосередньо належать до сфери охорони здоров'я: право на життя; право на охорону здоров'я; право на медичну допомогу; право на медичне страхування.

2. Права, які опосередковано стосуються охорони здоров'я: правовий захист від будь-яких незаконних форм дискримінації, пов'язаних зі станом здоров'я; оскарження неправомірних рішень і дій працівників закладів та органів охорони здоров'я; право на відшкодування як матеріальної, так і моральної шкоди, завданої життю та здоров'ю; право на захист у суді у разі порушення прав громадян у галузі охорони здоров'я та прав пацієнтів; право на достатній життєвий рівень; безпечне для життя і здоров'я навколишнє природне середовище; санітарно-епідемічне благополуччя території і населеного пункту; безпечні і здорові умови праці, навчання, побуту та відпочинку; право на участь в обговоренні проєктів законодавчих актів і внесення пропозицій щодо формування державної політики в галузі охорони здоров'я; право на участь в управлінні охороною здоров'я та проведенні громадської експертизи з цих питань; право на об'єднання в громадські організації з метою сприяння охороні здоров'я [7, с. 12].

Стосовно людиноцентризму, то, без всякого сумніву, сучасне його розуміння (як i ініціювання цього терміна та його імплементація у площину адміністративного права) по праву належить відомому українському адміністративісту професору В.Б. Авер'янову, наукові праці якого (передовсім початку III тисячоліття) пролили світло на визначення, розуміння та реалізацію його у рамках адміністративно-правової дійсності. Дуже складно заперечувати позицію цього фахівця, який зазначав, що «нині необхідність докорінного перегляду доктринальних оцінок адміністративного права підтверджується об'єктивними потребами згадуваної зміни самої ідеології публічної влади: від «керування» держави людиною - до “служіння» держави людині і суспільству в цілому. Отже, усе більше коло відносин у сфері здійснення публічної влади набуватиме ознак, невластивих «класичній» природі управління, котра традиційно характеризується усталеною формулою «влада-підпорядкування». У нових умовах людина, яка потраплятиме у сферу дії адміністративного права, має

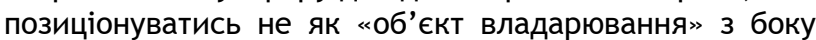
держави, а насамперед як головний «адресат» виконуваних публічною владою обов'язків, тобто як суб'єкт, якому має "служити» держава» [8, с. 401]. Без всякого сумніву, у сфері медичної діяльності, під час формування державою єдиного медичного простору, підхід має бути саме таким: людина має сприйматись як головний «адресат» виконуваних публічною владою обов'язків, тобто як суб'єкт, якому має «служити» держава. Служити і у частині побудови системи, де людина може отримати доступну та якісну медичну допомогу у зручний для себе спосіб.

Таким чином, проблематика єдиного медичного простору України у контексті його нормативно-правового забезпечення має перебувати у парадигмі розвитку вітчизняного адміністративного права. А вона, своєю чергою, базуючись на засадах людиноцентризму, здатна забезпечити пріоритет прав, свобод та законних інтересів пацієнтів під час надання медичної допомоги. 


\section{Правове забезпечення адміністративної реформи}

\section{Література}

1. Сіделковський О.Л. Правове забезпечення формування єдиного медичного простору України (теоретико-методологічні аспекти дослідження). Вісник Луганського державного університету внутрішніх справ імені Е.О. Дідоренка. 2018. № 4. С. 54-62.

2. Основи законодавства України про охорону здоров'я. Відомості Верховної Ради України. 1993. № 4. Ст. 19.

3. Стеценко С.Г. Медична реформа в Україні: право, політика, мораль. Публічне право. 2017. № 4. С. 57-61.

4. Сіделковський О.Л. Правове забезпечення єдиного медичного простору України: до постановки питання. Публічне право. 2018. № 2. С. 126-131.

5. Мельник Р.С. Загальне адміністративне право : навчальний посібник /Тихомиров А.В. Теория медицин- ской услуги и медицинского деликта : учебно-научое пособие. Москва : НП ИЦ «ЮрИнфоздрав», 2012. 110 с.

6. Стеценко С.Г. Медичне право України (реалізація та захист прав пацієнтів) : монографія / С.Г. Стеценко, В.О. Галай. Київ : Атіка, 2010. 168 с.

7. Авер'янов В.Б. Вибрані наукові праці / Упорядники: Андрійко О.Ф., (керівник колективу), Нагребельний В.П., Кисіль Л.Є., Педько Ю.С., Дерець В.А., Пухтецька А.А., Кірмач А.В., Люлька Л.В. ; За заг. ред.: Ю.С. Шемшученко, О.Ф. Андрійко. Київ : Інститут держави і права ім. В.М. Корецького НАН України, 2011. 448 с.

Сіделковський О. Л., кандидат медичних наук, директор клініки «Аксімед» 